\title{
Tony Hunt, A Forgotten Author - Péan Gattineau
}

\section{G. Matteo Roccati}

\section{(2) OpenEdition}

\section{Journals}

\section{Édition électronique}

URL : http://journals.openedition.org/studifrancesi/34298

DOI : 10.4000/studifrancesi.34298

ISSN : 2427-5856

Éditeur

Rosenberg \& Sellier

\section{Édition imprimée}

Date de publication : 1 novembre 2005

Pagination : 389

ISSN : 0039-2944

\section{Référence électronique}

G. Matteo Roccati, «Tony Hunt, A Forgotten Author - Péan Gattineau », Studi Francesi [En ligne], 146 (XLIX | II) | 2005, mis en ligne le 30 novembre 2015, consulté le 18 avril 2021. URL : http://

journals.openedition.org/studifrancesi/34298; DOI : https://doi.org/10.4000/studifrancesi.34298

Ce document a été généré automatiquement le 18 avril 2021.

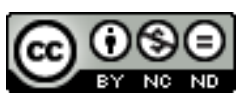

Studi Francesi è distribuita con Licenza Creative Commons Attribuzione - Non commerciale - Non opere derivate 4.0 Internazionale. 


\title{
Tony Hunt, A Forgotten Author - Péan Gattineau
}

\author{
G. Matteo Roccati
}

\section{RÉFÉRENCE}

TONY HUNT, A Forgotten Author - Péan Gattineau, "French Studies", LVIII, 3, 2004, pp.

313-326.

1 La vie de saint Martin de Tours (ms. Paris, BnF, fr. 1043, 10296 octosyllabes, deuxième quart du XIII ${ }^{\mathrm{e}}$ siècle), par le chanoine tourangeau Péan Gattineau (Paganus Gastinelli), est étudiée ici comme témoin significatif de l'évolution technique de la versification: par la pratique de l'enjambement, donnant lieu à des rejets importants, par la brisure du couplet, l'octosyllabe s'affranchit de l'unité de composition constituée par le couplet ou le vers. 